\title{
A Study on the Effective Integration of Mass entrepreneurship and innovation Education and Professional Education
}

\author{
Wang Chunxi, Wang Hongchao, Gan Juan \\ Xi'an Aeronautical University, Xi'an, Shaanxi, 710077,China
}

\begin{abstract}
Under the influence of a new round of scientific and technological revolution, the creator movement is advancing and developing in a global scope. Colleges and universities, as an important garden for talent training, are generally not motivated and innovative in classroom teaching. How to stimulate students' learning motivation and innovative development consciousness is a severe test that every university must face.
\end{abstract}

Keywords:Traveler; Mass entrepreneurship and innovation education; Professional education; Integration strategy

In the Internet era, the channels for acquiring knowledge are more diversified and rich. The traditional teaching concept has been unable to meet the learning needs of contemporary students. It is not conducive to the improvement of students' comprehensive quality and runs counter to the goal of contemporary talent cultivation. Therefore, the deep reform of teaching is the first step to cultivating talents. It is necessary not only to pay attention to the cultivation of students' professional ability, but also to pay attention to the cultivation of students' professional accomplishment and to lead them into the correct road of growing up and becoming talents.

I. The Strategy of Effective Integration of Mass entrepreneurship and innovation Education and Professional Education Based on the Concept of Creation

https://doi.org/10.47852/bonviewCETR2020010220

This is an open access article published by the BON VIEW PUBLISHING PTE. under the Creative Commons Attributions License. 


\section{A. Updating the teaching philosophy}

As the implementer of education, it is an important guarantee for the smooth development of education. However, in the actual teaching process, teachers' voice is exhausted, and students' silence is a common problem in the current teaching classroom. How to stimulate students' enthusiasm and initiative in learning is a major challenge faced by current educators ${ }^{[1]}$. Educators need to actively change the current teaching situation based on the concept of creating customers, strengthen the learning and training of teachers' professional skills, introduce the changes of current industrial structure, macro policy guidance and the learning needs of contemporary college students. To establish a sense of crisis, stimulate their sense of mission and responsibility for work reform, urge them to actively update their teaching concepts and teaching methods in the process of self-improvement, so as to lay a solid foundation for the comprehensive training work. High end talents. The specific implementation methods are as follows: first, strengthen the organization of teacher training. School leaders should actively organize teachers to participate in various kinds of innovation and entrepreneurship education lectures and seminars, participate in research in Colleges and universities, visit the creative base and entrepreneurial park of each university, and learn the successful teaching experience of each university. To optimize and update their teaching ideas. To encourage young teachers to participate in the education and training of creators, organize young teachers to carry out open source intelligent software teaching practice training, and improve teaching experience; second, combine virtual teaching and research section with public entrepreneurship and innovation education. Through the construction of "virtual teaching and research section", the "double training plan" is implemented. The teaching team members of virtual teaching and Research Office include professional leaders, high-level teachers, young and middle-aged teachers, enterprise tutors, etc. It fully reflects the professionalism of the teaching staff. At the same time, these high-quality teachers are responsible for and implement talent training plans including curriculum teaching, practical teaching, student guidance, quality evaluation, etc., and improve teaching quality and efficiency through high-quality teaching resources ${ }^{[2]}$.

\section{B. Introduction Course Reform for Freshmen}

In order to retain the students' heart and stimulate their subjective initiative in the classroom, in addition to actively reforming the traditional teaching concept and teaching mode, we also need to find a breakthrough to fully combine the entrepreneurship and innovation education with the major. Freshmen's view on the university campus is like a piece of white paper, knowing nothing about the major to be studied. Educators are like a colored pen, who can draw the desired color paper on the white. Only in this way can they adapt to the practical development of their major. It not only enables 
students to master the theoretical knowledge related to their major, but also introduces engineering examples on this basis, so that students can intuitively understand the value of their own specialty and professional application, so as to stimulate their enthusiasm for learning. Generate interest in selfmanagement, so as to improve their professional level. In Manchu era, teachers can take the information and communication major as the breakthrough point, effectively integrate the entrepreneurship and innovation education and professional education, and strengthen the students' understanding of the specialty. The first course of freshmen contact major is professional introduction. The traditional teaching idea is to improve students' understanding of this major through special lectures, so as to understand their future development trend and key technology major. However, this kind of teaching mode has limitations, which limits the scope of students' understanding of professional knowledge. At the same time, full-time teachers pay too much attention to the explanation of theoretical knowledge in classroom teaching, which easily ignores the dominant position of students' learning, resulting in the lack of interaction and communication between teachers and students. Therefore, students' personal views and ideas can not be answered or recognized, which makes students feel that their professional knowledge has nothing to do with real life, and their personal acquisition ability is weak, which eventually reduces their learning enthusiasm and even produces boredom. In order to create objective and professional teachers, we need to strengthen the reform of Freshmen's guiding course. In the classroom teaching of introduction course, it is not only necessary to strengthen students' engineering cognitive education and impart relevant professional knowledge to students, but also need professional teachers to consciously infiltrate the concept of "maker". With the modern advanced intelligent software platform as the practice carrier, we can complete our own intelligent hardware work with the help of the practice platform in a short time, obtain the joy of success, and then improve the students' interest in innovation and entrepreneurship ${ }^{[3]}$. The extra-curricular time on university campus is relatively sufficient, because freshmen are unfamiliar with the campus environment and life mode, and can not reasonably arrange their extracurricular activity time. Therefore, in addition to teaching practice for freshmen in professional introduction courses, professional teachers can also use them to actively organize a series of creative activities with the theme of "freshman traveler competition" in their spare time. We should create a good atmosphere for students' innovation, encourage them to participate actively, carry out technical innovation training, and enhance their independent ability to innovate. Under the background of a certain period of time, the market can fully verify the application value of contemporary knowledge, and combined with changes, according to the current market situation, use existing science and technology and professional knowledge to transform products into markets. 
Promote a new round of economic and social benefits. Therefore, based on the concept of the creator, the specific implementation strategies of the in-depth reform of college freshmen guidance course are as follows: first, curriculum. The content module of "creating guest and open source courseware" is embedded in the professional introduction course, as well as the related knowledge of open source hardware module and development environment. Professionals describe the application of open source hardware sharing learning platform in detail. In the actual classroom teaching process, teachers guide and lead students to complete LED lights, color running lights and other cases, at the same time, arrange students' after-school outward bound training, including electronic doorbell, music player, Bluetooth communication, infrared dimming and other innovative cases; second, organizational form. The number of teachers in each major has increased from about 100 to about 30 groups. The original step-by-step teacher was transferred to the professional laboratory. At the same time, a young teacher was assigned to be responsible for the guidance of a class, and multiple laboratories were allowed to conduct experiments together. In the process experiment, the students are divided into groups, each group is composed of three members, and each group selects a team leader. In each group, a set of open source hardware in each group that is shared by group members. The group leader is responsible for keeping the suite, coordinating the team members and assigning tasks; the third is the assessment method. Students complete the assigned innovation projects in groups or submit complete research reports and physical labor videos. It is difficult for teachers to evaluate the results of innovation projects according to their various functional effects and degrees. In addition, the team leader, with the unanimous consent of the group members, scores the contribution of each group member in the creative project in the research report, and finally the teacher scores it. Fourth, through the use of students' extracurricular time, a series of tourist competition theme activities are carried out to create a harmonious innovation and entrepreneurship atmosphere for students. This activity must run through the whole freshman teaching. In order to stimulate students' interest in innovation and entrepreneurship, cultivate students' hands-on ability and innovation ability, including launching ceremony, visiting the college's creative space, answering questions on the spot by enterprise engineers ${ }^{[4]}$.

C. Developing a mechanism for independent professional operation

Based on the concept of maker, only through the support of top-level design and system guarantee, can a long-term mechanism be formed in the University within four years, and the effective integration of innovation and entrepreneurship education and professional education can be realized. As an important garden for training talents, universities need not only excellent professional knowledge, but also excellent professional practice and application ability to cultivate more comprehensive high- 
end talents. Therefore, in the process of formulating talent training programs, in addition to the need to set up innovation and entrepreneurship courses, we also need to integrate the past extracurricular practice and innovation activities. The main purpose of innovation and entrepreneurship courses is to popularize the latest entrepreneurial ideas and innovative spirit to students with innovative methods; the main purpose of integrating extracurricular practice and innovation activities is to help students accumulate practical experience, and then improve Professional skills. Practice and innovation activities include discipline competition, major projects, open projects, teachers' scientific research projects, etc. independent professional practice elective courses are set up, and credit required time is set. In this way, students can not only obtain credits, complete activity process records and specific individual scores through this activity, but also use this activity to find out their own learning deficiencies, and make targeted improvements to promote personal progress ability. At the same time, through this activity, full-time teachers quantify their performance in a systematic way, which helps to stimulate their enthusiasm and potential ${ }^{[5]}$.

\section{Innovation of the Effective Integration of Mass entrepreneurship and innovation Education and Professional Education}

A. Innovative ideas

A good beginning can get twice the result with half the effort. It takes the engineering cognitive education of freshmen as the starting point, and the guidance course as the starting point. Through diversified teaching methods, infiltrate the concept of maker to students, stimulate students' professional interest, cultivate students' professional practice ability, and promote the effective integration of entrepreneurship and innovation education and professional education through reverse design of teaching process.

B. System innovation

The introduction of practical teaching cases in the professional introduction course, through the development of guest theme creation activities, create a good creative atmosphere and stimulate students' creative potential. At the same time, through the establishment of professional independent practice courses, promote the integration of public entrepreneurship and innovation education and professional education $^{[6]}$.

C. Institutional innovation

Reform the evaluation mechanism of introduction course, cultivate students' innovation ability and innovation consciousness, establish the management and implementation system of professional independent practice course, mobilize the enthusiasm of teachers, and lay a good foundation for the effective integration of public entrepreneurship, innovation education and vocational education. 


\section{Conclusion}

In a word, under the background of the new era, higher requirements have been put forward for talent training standards. As an important field of talent cultivation, colleges and universities need fulltime teachers to actively change their teaching concepts and teaching models. In the guidance course teaching, the innovation and entrepreneurship education and professional education are effective integration. At the same time, we should consciously transfer the positive energy of customer creation to students, cultivate their awareness of innovation and entrepreneurship, improve their professional ability and promote their all-round development.

Acknowledgement

This work is supported in part by 2020 higher education research project of Xi'an Institute of Aeronautics (2020GJ008): Research on the integration of innovation and entrepreneurship education and professional education in Application-oriented Universities.Soft Science Project of Shaanxi Science and Technology Department in 2019(2019KRM052): Research on the Transfer and Transformation Model of Scientific and Technological Achievements in the Colleges and Universities

\section{References}

[1] Li Xuehua, Shen Bingxia, Li Fubing, et al. Exploration on the Integration of Mass entrepreneurship and innovation Education and Professional Education Based on the Concept of J]. Creation Industry and Information Education ,2018,(11):6-12.

[2] Yang Fan. A Practical Study on the Integration of Mass entrepreneurship and innovation Education into the Cross-border E-commerce Course of Business English Specialty in Higher Vocational Colleges [J].] Journal of Anyang Normal University, No.119(3):142-145.,2019

[3] Hu Yuhang. A Study on the Cultivation Mode of Creative Education Talent in Higher Vocational Colleges [J].] Based on the Integration of Resources Journal of Hebei Tourism Vocational College 23(04):73-76.

[4] Zhang Yan. A Study on Innovation and Entrepreneurship Education in Colleges and Universities Based on Creative J]. Education Journal of Heilongjiang Institute of Education.

[5] Rao Huan. An Analysis of the Integration Path between Creative Education and Higher Vocational Professional Education [J].]; and Friends of the Humanities ,2019,(20):111-112.

[6] Cheng is beautiful. Discussion on the Integration Strategy of Creative Education and Basic Education[J].Education and Equipment Research ,2019,35(5):13-20. 